\title{
QUALITY OF WATER SOURCES USED AS DRINKING WATER IN A BRAZILIAN PERI-URBAN AREA
}

\author{
Maria Tereza Pepe Razzolini*, Wanda Maria Risso Günther, Francisca Alzira dos Santos Peternella, Solange Martone- \\ Rocha, Veridiana Karmann Bastos, Thaís Filomena da Silva Santos, Maria Regina Alves Cardoso
}

Faculdade de Saúde Pública, Universidade de São Paulo, São Paulo, SP, Brasil.

Submitted: June 24, 2010; Returned to authors for corrections: July 25, 2010; Approved: January 13, 2011.

\begin{abstract}
The objective of this paper was to assess bacteriological quality of drinking water in a peri-urban area located in the Metropolitan Region of São Paulo, Brazil. A total of 89 water samples were collected from community plastic tanks and 177 water samples from wells were collected bimonthly, from September 2007 to November 2008, for evaluating bacteriological parameters including: Escherichia coli, Enterococcus and heterotrophic plate count (HPC). Clostridium perfringens was investigated in a subsample (40 samples from community plastic tank and 40 from wells). E. coli was present in $5(5.6 \%)$ samples from community plastic tanks (2.0 - 5.1x10 MPN/100mL) and in 70 (39.5\%) well samples (2.0 - 8.6x10 MPN/100mL). Thus, these samples were not in accordance with the Brazilian Regulation. Enterococcus was detected in 20 (22.5\%) samples of the community plastic tanks (1 to $79 \mathrm{NC} / 100 \mathrm{~mL})$ and in $142(80.2 \%)$ well samples (1 to >200 $\mathrm{NC} / 100 \mathrm{~mL})$. . perfringens was detected in $5(12.5 \%)$ community plastic tanks samples and in $35(87.5 \%)$ wells samples $(2.2$ to $>16 \mathrm{MPN} / 100 \mathrm{~mL})$. HPC were above $500 \mathrm{CFU} / \mathrm{mL}$ in $5(5.6 \%)$ waters from community plastic tanks. In wells samples, the HPC ranged from $<1$ to $1.6 \times 10^{4} \mathrm{CFU} / \mathrm{mL}$. The residual chlorine did not attend the standard established in the drinking water legislation $(0.2 \mathrm{mg} / \mathrm{L})$, except in 20 (22.5\%) samples. These results confirm the vulnerability of the water supply systems in this peri-urban area what is clearly a public health concern.
\end{abstract}

Key words: Clostridium perfringens, Escherichia coli, Enterococcus, peri-urban area, drinking water

\section{INTRODUCTION}

The Metropolitan Region of São Paulo (MRSP) is considered the most industrialized and densely populated in Brazil, houses approximately 18 millions inhabitants in 39 adjacent cities. In spite of being the most developed region in Brazil, one can observe peri-urban areas there with serious problems related to drinking water supply and sanitation conditions. These underprivileged areas with subnormal urbanization and inadequate sanitation arrangements (lack of collection, treatment and sanitary disposal of wastewater and of solid waste) directly impact on the quality of water and expose the population to unhealthy conditions.

This kind of occupation usually occurs in Water

\footnotetext{
*Corresponding Author. Mailing address: School of Public Health, University of São Paulo, São Paulo, Brazil Av. Dr Arnaldo $7151^{\circ}$ andar - 01246-904 São Paulo - SP - Brazil.; Tel: (55)(11) 30617888 Fax: (55)(11) 3061 7732.; E-mail: razzolini@usp.br
} 
Catchments Areas destined to drinking water supply, causing increased pollution load in the watersheds with the consequent change in water quality (5). The probability of occurring waterborne and vector borne diseases is heightened, especially among vulnerable populations as children, the elderly and imunocompromised people $(4,8)$.

According to the WHO (25), of the 102 major diseases which were covered by the World Health Report in 2004, environmental risk factors contributed to disease burden in 85 categories. Diarrhoeal disease were included in these categories, being estimated that $88 \%$ of the diarrhoea burden of disease is attributable to environment and associated with risk factors such as unsafe drinking water and poor sanitation and hygiene (9).

There are approximately 2 million people living in irregular settlements around protected watershed areas in MRSP. Important social, sanitary and public health concern has been arisen with this scenario of urban sprawling and social exclusion.

The purpose of this study was to assess bacteriological quality of drinking water in a peri-urban area located in Suzano, one of the cities of the MRSP. This area shelters an important watershed which is responsible for water supply to approximately 3 million inhabitants of the MRSP.

\section{MATERIALS AND METHODS}

\section{Studied Area Characterization}

Suzano municipality is part of the MRSP and is located northeast of São Paulo $\left(23.36^{\circ} \mathrm{S}\right.$ and $\left.46.20^{\circ} \mathrm{W}\right)$. It has a population of 304,414 habitants, $97.5 \%$ of urbanization rate, $2.9 \%$ of population geometric growth rate, $87.6 \%$ of drinking water supply and $66 \%$ of sewage collection (18), $64 \%$ of its territory is within Protection water catchments areas issued by the São Paulo State Law N ${ }^{\circ} 898 / 75$ and 1172/76.

Three settlements irregularly established in the Protection Water Catchment Area, denominated as Vila Ipelândia, Vila
Nova Ipelândia and Quinta Divisão were identified.

There are approximately 2,000 inhabitants in these settlements and they are not considered in the official state budget and urban planning. Treated water is supplied for them by truck-tank and transferred to community plastic tanks with capacity of $5 \mathrm{~m}^{3}$. These reservoirs are disposed at public areas and intend to provide water for five to seven families, although the water withdrawals are not controlled. Water has been withdrawn by hoses, storage in vessels or others recipients such as buckets. The cleaning of community plastic tanks is irregular and the community is in charge of this task. Researchers observed that some community plastic tanks were with broken or ripped lid and, sometimes, were empty. The tap of the tanks is located in the lower part, very close to the soil and grass and thus exposed to animal contact. As this situation leads to conflict, people look for an alternative water source by digging a well in their backyard. The sewage is disposed in septic tanks, in basic latrines or directly in the water bodies. It is important to highlight that the construction of the wells and septic tanks is done without any sanitary criterion. The solid waste is burned, dug or launched on unused land (14).

\section{Sample and sampling}

All the 12 community plastic tanks and a sample of wells $(n=26)$ were included in the study. The study settlements were divided into small areas and at least one well was selected from each one, so that all field characteristics were represented in the sample. The water samples were collected bimonthly from September 2007 to November 2008. Thus, a total of 89 water samples were collected from community plastic tanks and 177 from wells. C. perfringens were counted in 40 samples from community plastic tanks and in 40 samples from wells. The samples were collected according to the Standard Methods for Examination of Water and Wastewater (20), in sterile disposable bottles containing sodium tiossulphate to inactivate chlorine, chilled for transportation and examined within a 24 hour period. Residual chlorine was measured in samples from 
the community plastic tanks by a colorimetric method using Free-chlorine Analyser Policontrol®. Water temperatures were taken using mercury column and $\mathrm{pH}$ value using universal paper $\mathrm{pH}$ indicator. The occurrence of rainfall at the last 24 hours was recorded. The bacteriological parameters were analysed in duplicate as follows:

E. coli: The determination of $E$. coli was carried out by Multiple-Tube Technique using EC-MUG broth (Difco®, Detroit, MI, USA) by examining positive tubes for fluorescence using a long-wavelength (366nm) ultraviolet lamp after incubating for 24 hours at $35 \pm 0.5^{\circ} \mathrm{C}$, according to the Standard Methods for Examination of Water and Wastewater (20).

Enterococcus: The enumeration of Enterococcus was done by filtering $100 \mathrm{~mL}$ of the water sample in a $0.45 \mu \mathrm{m}$ porosity and $47 \mathrm{~mm}$ diameter membrane filter, according to the Standard Methods for Examination of Water and Wastewater (20). The membranes were transferred to Petri dishes containing $\mathrm{mE}$ agar for Enterococcus (Difco) and incubated for 48 hours at $41.5^{\circ} \mathrm{C}$. After incubation time, the membranes containing typical colonies were transferred to Petri dishes containing EIA substrate (Difco) and incubated for 20-30 minutes at $41.5^{\circ} \mathrm{C}$ as a confirmatory test.

Clostridium perfringens: The determination of $C$. perfringens was carried out by Multiple-Tube Technique using DRCM medium (Difco) and, as a confirmatory step, using Litmus Milk broth (Difco) according to HSMO (13), with incubation time of 48 hours at $35 \pm 0.5^{\circ} \mathrm{C}$.

Heterotrophic Plate Count (HPC): The HPC was performed according to the Standard Methods for Examination of Water and Wastewater (20) by pour plate method using Plate Count Agar (Difco) with incubation time of 48 hours at $35 \pm 0.5^{\circ} \mathrm{C}$.

\section{RESULTS AND DISCUSSION}

Table 1 summarizes the percentage of positive samples for faecal indicator in community plastic tanks and wells samples. The drinking water from the community plastic tanks was of better bacteriological quality than the water from the wells, probably because of the source used to supply the community plastic tanks.

Table 1. Percentage of positive samples by fecal indicator (Escherichia coli, Enterococcus and Clostridium perfringens) in community plastic tanks and wells assessed in a peri-urban area of Suzano, São Paulo, September 2007 - November 2008.

\begin{tabular}{ccc}
\hline Fecal Indicator & Community plastic tanks & Wells \\
\hline Escherichia coli & $5.6 \%(\mathrm{n}=89)$ & $39.5 \%(\mathrm{n}=177)$ \\
Enteorococcus & $23.5 \%(\mathrm{n}=89)$ & $80.2 \%(\mathrm{n}=177)$ \\
Clostridium perfringens & $12.5 \%(\mathrm{n}=40)$ & $87.5 \%(\mathrm{n}=40)$ \\
\hline
\end{tabular}

Out of 89 samples from 12 water community plastic tanks, $5(5.6 \%)$ were positive for $E$. coli, with concentrations ranging from 2.0 to $5.1 \times 10^{4} \mathrm{MPN} / 100 \mathrm{~mL}$. With regard to the samples from wells, E. coli was detected in 70 (39.5\%) with concentrations from 2.0 to $8.6 \times 10^{4} \mathrm{MPN} / 100 \mathrm{~mL}$. Thus, these samples were not in accordance with the Brazilian Regulation issued by the Brazilian Health Ministry (3), which has established as standard the absence of $E$. coli or thermotolerant coliforms in drinking water.

Different water sources were investigated by other authors as Sánchez-Pérez et al (17), Welch et al (23) and Amaral et al (1), who found higher level of faecal contamination than we did in this study. Sánchez-Pérez et al (17), studying sources of water that supplied 93 households in Chiapas (Mexico), 
observed that the water quality was poor in $67 \%$ of the households and $36 \%$ of them presented E. coli. Study carried out by Welch et al (23) assessed water quality in 167 households in a rural community of Trinidad, 119 (71.3\%) of these households had treated water supplied by pipe borne, standpipes and truck borne while 48 (28.7\%) used water from rivers, wells, streams and rain. Faecal coliforms were present in $79 \%$ of analyzed samples, wells, streams and rain and a significant number of $E$. coli isolated exhibited virulence markers. According to the authors, the poor quality of water can reflect inadequate chlorination and storage as well as poor water handling. Amaral et al (1) assessed drinking water quality from reservoirs and wells in rural properties in the northeast of São Paulo State. They found high percentage of samples (90\% and $83 \%$ in the rain and drought, respectively) that did not meet the quality standards set up by the Brazilian legislation. This might have been a result of lack of water treatment or low frequency of reservoir cleaning.

In this study, Enterococcus was present in 21 (23.5\%) samples from the community plastic tanks, with concentrations ranging from 1 to $79 \mathrm{NC} / 100 \mathrm{~mL}$, and in 142 (80.2\%) samples from wells, with concentrations from 1 to $>200 \mathrm{NC} / 100 \mathrm{~mL}$. These organisms were present even in samples where E. coli was absent.

This fecal indicator is not established by the Brazilian regulation, but it has been used as a complementary faecal indicator for assessing water quality $(11,19)$. In some cases, these bacteria can be more effective to assess sanitary quality of drinking water than the coliform group. Their die off is slower than that observed for the coliform in water, their persistence patterns are similar to those of potential waterborne pathogens bacteria, and they have greater resistance to chlorination $(6,10,16,21,24)$.

Gundry et al (12) bring several references from observational studies on point-of-use water quality, one of them considering drinking water of poor quality when concentrations of Enterococcus are higher than $99 \mathrm{NC} / 100 \mathrm{~mL}$.
In the present study, $21(11.8 \%)$ well samples were above this concentration.

The remote faecal indicator, Clostridium perfringens concentration, was observed in $5(12.5 \%)$ community plastic tanks samples and in $35(87.5 \%)$ wells samples with concentrations ranging from 2.2 to $>16 \mathrm{MPN} / 100 \mathrm{~mL}$.

Samples containing two or more indicators were frequent as shown in Table 2. The simultaneous presence of E. coli and Enterococcus was observed in $3.4 \%$ and $39.0 \%$ of the community plastic tank and well samples, respectively. On the other hand, our findings show that presence of Enterococcus in the absence of $E$. coli occurred in $41.2 \%$ of the well samples, highlighting the importance of taking into account these organisms to assess drinking water quality and the vulnerability of certain sources of water to faecal pollution, especially wells.

With regard to HPC, $5(5.6 \%)$ community plastic tank samples had concentrations higher than $500 \mathrm{CFU} / \mathrm{mL}$, the upper limit established by the law. Well samples had HPC from $<1$ to $1.6 \times 10^{4} \mathrm{CFU} / \mathrm{mL}$. The Brazilian regulation does not specify HPC limits for waters from wells. However, although there is no evidence of associations between any of these organisms with gastrointestinal infections (24), high levels of these bacteria can indicate presence of abundant organic matter and favour environment to biofilm formation, which can shelter pathogenic organisms $(15,22)$.

The values of residual chlorine did not meet the standard established by the drinking water legislation $(0.2 \mathrm{mg} / \mathrm{L})$, except in $20(22.5 \%)$ samples with detected values of residual chlorine of $0.2 \mathrm{mg} / \mathrm{L}$ or higher. E. coli was detected in $4(20.0 \%)$ samples and Enterococcus in $3(15.0 \%)$ from community plastic tanks with chlorine concentrations above $0.2 \mathrm{mg} / \mathrm{L}$.

In the community plastic tanks samples, temperature measures varied from 15 to $27^{\circ} \mathrm{C}$ with mean of $21.2^{\circ} \mathrm{C}\left( \pm 6.3^{\circ} \mathrm{C}\right)$ and $\mathrm{pH}$ values from 4.0 to 8.0 with mean of $5.8( \pm 2.1)$. In the well samples, temperature measures varied from 15 to $29^{\circ} \mathrm{C}$ with mean of $21.3^{\circ} \mathrm{C}\left( \pm 8.4^{\circ} \mathrm{C}\right)$, and $\mathrm{pH}$ values from 4.0 to 8.0 , with median of $5.4( \pm 2.2)$. The temperature and the $\mathrm{pH}$ values 
did not vary throughout the study period and thus no microorganism seasonal variation could be observed. have indicated its effect on the bacteriological water quality throughout the study period, as shown in Figure 1.

It was not observed a defined rainfall season that could

Table 2. Percentage of detection by fecal indicators (Escherichia coli, Enterococcus and Clostridium perfringens) and HPC counts in samples from community plastic tanks and wells in a peri-urban area of Suzano, São Paulo, September 2007 - November 2008.

\begin{tabular}{|c|c|c|c|}
\hline Bacteriological parameters & Community plastic tanks (\%) $(\mathrm{n}=89)$ & Wells $(\%)$ & $(n=177)$ \\
\hline E.coli + / Enterococcus + & 3.4 & 39.0 & \\
\hline E.coli - / Enterococcus + & 21.3 & 41.2 & \\
\hline E. coli + / Enterococcus - & 2.2 & 1.1 & \\
\hline E. coli - / Enterococcus - & 73.0 & 18.6 & \\
\hline E. coli $+/$ C. perfringens $-*$ & 5.0 & 5.0 & \\
\hline E. coli + / C. perfringens $+^{*}$ & 0.0 & 25.0 & \\
\hline E coli - / C. perfringens -* & 82.5 & 5.0 & \\
\hline E. coli-/ C. perfringens $+^{*}$ & 12.5 & 52.5 & \\
\hline Enterococcus $+/$ C. perfringens $+*$ & 10.0 & 72.5 & \\
\hline Enterococcus $+/$ C. perfringens $-*$ & 7.5 & 2.5 & \\
\hline Enterococcus - / C. perfringens -* & 77.5 & 10.0 & \\
\hline Enterococcus - / C. perfringens $+*$ & 2.5 & 12.5 & \\
\hline E. coli $+/$ HPC $(>500 \mathrm{CFU} / \mathrm{mL})$ & 0.56 & 14.1 & \\
\hline Enterococcus + / HPC (>500CFU/mL) & 1.6 & 23.7 & \\
\hline C. perfringens $+/ \mathrm{HPC}(>500 \mathrm{CFU} / \mathrm{mL})^{*}$ & 2.5 & 20.0 & \\
\hline
\end{tabular}

\section{+ Presence / - Absence}

$* \mathrm{n}=40$

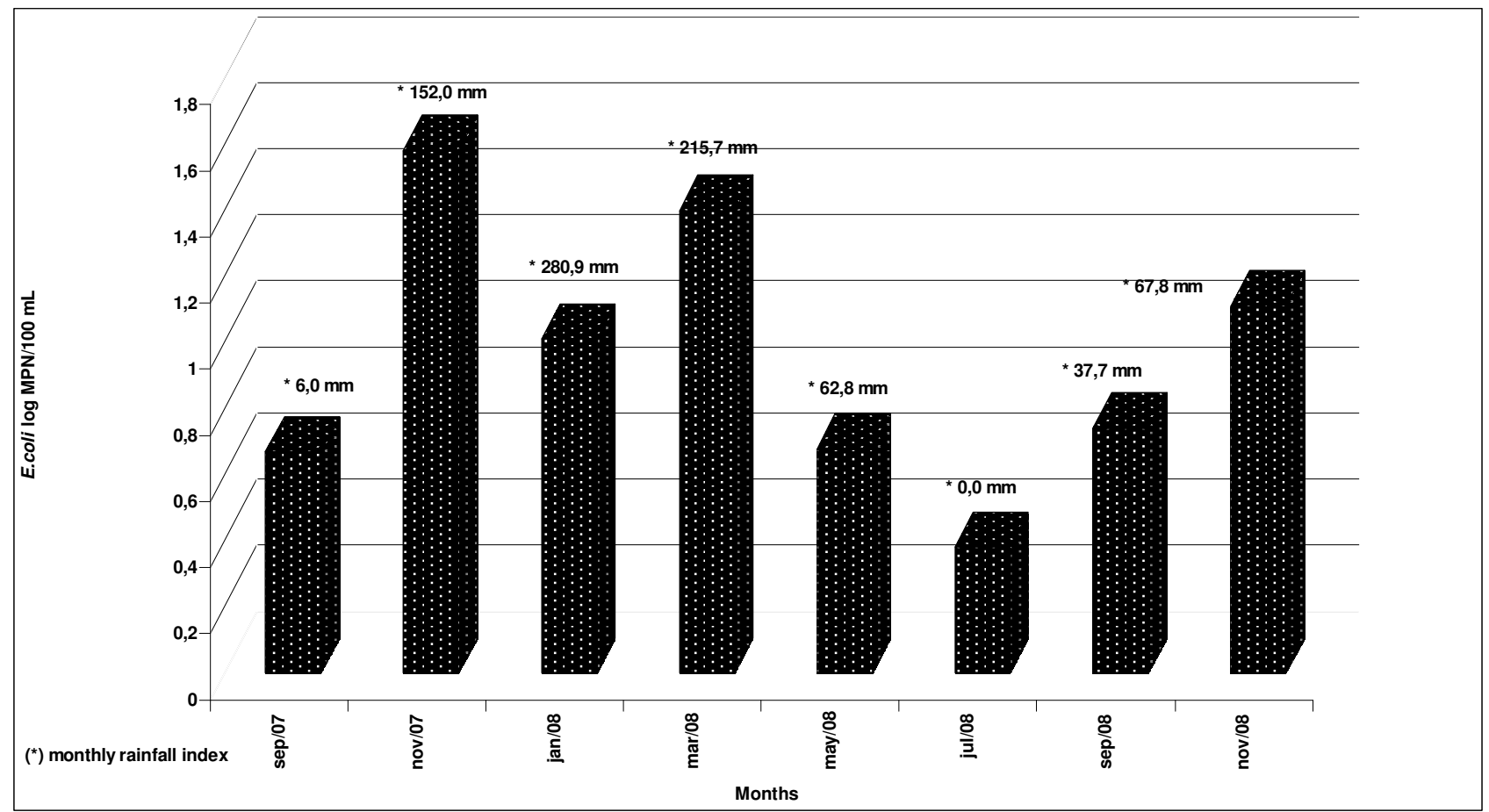

Figure 1. E. coli concentration in wells samples with precipitation index (mm), by month, Suzano, São Paulo, September 2007 November 2008 . 


\section{CONCLUSIONS}

The results of this study confirm the vulnerability of water supply systems in irregular settlements, where people are exposed to environmental risk factors such as waterborne pathogens able to cause diarrhoeal disease and other illnesses.

This research can bring technical bases to improve intervention measures aiming at enhancing quality of life for populations living in peri-urban areas with similar conditions.

\section{ACKNOWLEDGEMENTS}

We would like to thank FAPESP - Fundação de Amparo à Pesquisa do Estado de São Paulo for its financial support, and also $\mathrm{CNPq}$ - Conselho Nacional de Desenvolvimento Científico e Tecnológico - for the internship. The authors were partially supported by the CNPq (scholarship 303049/2007-3 to M.R.A.C. and 305071/2008-4 to W.M.R.G.)

\section{REFERENCES}

1. Amaral, L.A. do; Nader Filho, A.; Rossi Júnior, O.D.; Ferreira, F.L.A.; Barros, L.S.S. (2003). Água de consumo humano como fator de risco à saúde em propriedades rurais. Rev. Saúde Pública. 37(4), 510-514.

2. BRASIL. (2000). CONAMA - Conselho Nacional do Meio Ambiente 274 de 29/11/2000; Estabelece os critérios de balneabilidade em águas brasileiras. Available at: http://www.mma.gov.br/port/conama/res/res00/ res27400.html. Accessed 27 July 2010.

3. BRASIL. (2004). Ministério da Saúde. Portaria 518 de 25/03/2004; Estabelece os procedimentos e responsabilidades relativos ao controle e vigilância da qualidade da água para consumo humano e seu padrão de potabilidade, e dá outras providências. Available at: http://dtr2001. saude.gov.br/sas/PORTARIAS/Port2004/GM/GM-518.htm. Accessed 27 July 2010

4. Costa, S.S.; Heller, L.; Brandão, C.C.S.; Colosimo, E.A. (2005). Indicadores epidemiológicos aplicáveis a estudos sobre a associação entre saneamento e saúde de base municipal. Eng. Sanit. Ambient. 10(2), 118-127.

5. Ducrot, R.; Carvalho, Y.M.C.; Jacobi, P.R.; Clavel, L.; Barban, V.; Madazio, V.; Rabak, C.S.; Reydon, B.P.; Arruda, F.B.; Ramos, H.H.; Sato, G.S.; Sichman, J.S.; Menezes, L.C.B.; Vicente, M.C.M.; Lima, M.R.; Arteiro, M.G.; Castro, P.M.G.; Bommel, P.; Granja, S.I.B.;
Martins, S.S.; Sendacz, S.; Franca, T.J.F.; Günther, W.M.R. (2007). Building capacities to tackle the infrastructural and environmental crisis in São Paulo: Role-playing games for participatory modelling. In: Butterworth, J., Ducrot, R., Faysse, N., Janakarajan (eds). Peri-urban water conflicts - Supporting dialogue and negotiation. Technical Paper Series 50. IRC International Water and Sanitation Centre, Delft, the Netherlands, p.77-112.

6. EA - Environmental Agency . 2002. The microbiology of drinking water (2002). Part I - Water Quality and Health. Avalaible at: http://www.environment-agency.gov.uk/static/documents/Research/mdw part1.pdf. Accessed 28 July 2010.

7. Eshcol, J.; Mahapatra, P.; Keshapagu, S. (2009). Is fecal contamination of drinking water after collection associated with household water handling and hygiene practices? A study of urban slum households in Hyderabad, India. J. Water Health. 7(1):145-154.

8. Fewtrel, L.; Kaufman, R.B.; Kay, D.; Enanoria, W.; Haller, L.; Colford, J.M. (2005). Water, sanitation and hygiene interventions to reduce diarrhea in less developed countries: a systematic review and metaanlysis. Lant Infect Dis. 5:42-52.

9. Fewtrell, L.; Prüss-Üstüm, A.; Bos, R.; Gore, F.; Bartram, J. (2007). Water, sanitation and hygiene: quantifying the health impact at national and local levels in countries with incomplete water supply and sanitation. WHO Environmental Burden of Diseases Series n ${ }^{\circ} 15,71$ pages.

10. Gerba, C. (2000). Indicator Microorganisms. In: R.M. Maier, I.L.Pepper and C.P. Gerba (eds.). Environmental Microbiology. Academic Press, San Diego, CA, USA, p.491-503.

11. Grenfell, P.; Little, C.L.; Surman-Lee, S.; Greenwood, M.; Averns, J.; Westacott, C.; Lane, C.; Nichols, G. (2008). The microbiological quality of potable water on board ships docking in the Channel Islands: an association of Port Health Authorities and Health Protection Agency study. J. Water Health. 6(2), 215-224.

12. Gundry, S.; Wright, J.; Conroy, R. (2004). A systematic review of the health outcomes related to household water quality in developing countries. J. Water Health. 2(1), 1-13.

13. HSMO. The bactreriological examination of water supplies., $5^{\text {th }}$ ed. London. (1977). Department of Health and Social Security Welsh Office. Department of Environment. Reports on public health and medical subjects $\mathrm{N}^{\mathrm{o}} 71$.

14. IBGE Instituto Brasileiro de Geografia e Estatística. (2004). Atlas de Saneamento [CD ROM].

15. LeChavalier, M.W.; Welch, N.J.; Smith, D.B. (1996). Fullscale studies of factors related to coliform regrowth in drinking water. Appl. Environ. Microbiol. 62, 2201-2211.

16. Méndez, J.; Audicana, A.; Cancer, M.; Isern, A.; Llaneza, J.; Moreno, B.; Navarro, M.; Tarancón, M.L.; Valero, F.; Ribas, F.; Jofre, J.; Lucena, F. (2004). Assessment of drinking water quality using indicator bacteria and 
bacteriophages. J. Water Health. 2(3), 201-214.

17. Sánchez-Pérez, H.J.; Vargas-Morales, M.G.; Méndez-Sánchez, J.D. (2000). Calidad bacteriológica del agua para consumo humano en zonas de alta marginación de Chiapas. Salud Púb. Méx. 42(5), 397-406.

18. SEADE-Fundação Sistema Estadual de Análise de Dados, Sistema de documentação sobre população no Brasil. Available at: http://www.seade.sp.gov.br/produtos/perfil. Accessed 28 July 2010.

19. Sherpa, A.M.; Byamukama, D.; Shrestha, R.; Haberl, R.; Mach, R.L.; Farnleitner, H. (2009). Use of faecal pollution indicators to estimate pathogen die off conditions in source separated faeces in Katmandu Valley, Nepal. J. Water Health. 7(1), 97-107.

20. Standard Methods for the Examination of Water and Wastewater.(1998). $21^{\text {st }}$ edition, American Public Health Association/American Water Works Association/ Water Environment Federation, Washington, DC, USA.

21. Toranzos, G.A.; McFetters, G.A.; Borrego, J.J. (2002). Detection of microorganisms in environmental freshwaters and drinking water. In:
Hurst, C.J., Crawford R.L., Knudsen G.R., McInerney M.J., Stetzenbach L.D. (eds). Manual of Environmental Microbiology. ASM Press, Washington, DC,USA, p.205-219.

22. Trevett, A.F.; Carter, R.C.; Tyrrel, S.F. (2005). The importance of domestic water quality management in the context of faecal-oral disease transmission. J. Water Health. 3(3), 259-270.

23. Welch, P.; David, J.; Clarke, W.; Trinidade, A.; Penner, D.; Bernstein, S.; McDougall, L.; Adesiyum, A.A. (2000). Microbial quality of water in rural communities of Trinidad. Rev. Panam Salud Publica/Pan Am J Public Health. 8(3), 172-180.

24. World Health Organization .(2004). Guidelines for Drinking-water Quality, 3rd edition, Recommendations, Geneve, 2004.

25. WHO - World Health Organization. (2006). Preventing disease through healthy environments: towards an estimate of the environmental burden of disease. Geneve, 2006. 